\title{
High concentrations of biological aerosol particles and ice nuclei during and after rain
}

\author{
J. A. Huffman ${ }^{1,2}$, A. J. Prenni ${ }^{3}$, P. J. DeMott ${ }^{3}$, C. Pöhlker ${ }^{2}$, R. H. Mason ${ }^{4}$, N. H. Robinson ${ }^{5}$, J. Fröhlich-Nowoisky ${ }^{2}$, \\ Y. Tobo ${ }^{3}$, V. R. Després ${ }^{6}$, E. Garcia ${ }^{3}$, D. J. Gochis ${ }^{7}$, E. Harris ${ }^{2}$, I. Müller-Germann ${ }^{2}$, C. Ruzene ${ }^{2}$, B. Schmer ${ }^{2}$, \\ B. Sinha ${ }^{2,8}$, D. A. Day ${ }^{9}$, M. O. Andreae ${ }^{2}$, J. L. Jimenez ${ }^{9}$, M. Gallagher ${ }^{5}$, S. M. Kreidenweis ${ }^{3}$, A. K. Bertram ${ }^{4}$, and \\ U. Pöschl ${ }^{2}$ \\ ${ }^{1}$ Department of Chemistry and Biochemistry, University of Denver, 2190 E. Illif Ave., Denver, CO, 80208, USA \\ ${ }^{2}$ Max Planck Institute for Chemistry, P.O. Box 3060, 55020, Mainz, Germany \\ ${ }^{3}$ Department of Atmospheric Science, Colorado State University, 1371 Campus Delivery, Fort Collins, CO, 80523, USA \\ ${ }^{4}$ Department of Chemistry, University of British Columbia, Room D223, 2036 Main Mall, Vancouver, BC, V6T1Z1, Canada \\ ${ }^{5}$ Centre for Atmospheric Sciences, University of Manchester, Simon Building, Oxford Road, Manchester, M139PL, UK \\ ${ }^{6}$ Institute for General Botany, Johannes Gutenberg University, Müllerweg 6, 55099, Mainz, Germany \\ ${ }^{7}$ National Center for Atmospheric Research, P.O. Box 3000, Boulder, CO, 80307, USA \\ ${ }^{8}$ IISER Mohali, Department of Earth and Environmental Science, Sector 81, S. A. S. Nagar, Manauli PO, 140306, India \\ ${ }^{9}$ Cooperative Institute for Research in the Environmental Sciences and Department of Chemistry and Biochemistry, \\ University of Colorado, Boulder, CO, USA
}

Correspondence to: J. A. Huffman (alex.huffman@du.edu), A. J. Prenni (anthony.prenni@ colostate.edu),

A. K. Bertram (bertram@chem.ubc.ca), and U.Pöschl (u.poschl@mpic.de)

Received: 18 December 2012 - Published in Atmos. Chem. Phys. Discuss.: 16 January 2013

Revised: 25 May 2013 - Accepted: 27 May 2013 - Published: 1 July 2013

\begin{abstract}
Bioaerosols are relevant for public health and may play an important role in the climate system, but their atmospheric abundance, properties, and sources are not well understood. Here we show that the concentration of airborne biological particles in a North American forest ecosystem increases significantly during rain and that bioparticles are closely correlated with atmospheric ice nuclei (IN). The greatest increase of bioparticles and IN occurred in the size range of 2-6 $\mu \mathrm{m}$, which is characteristic for bacterial aggregates and fungal spores. By DNA analysis we found high diversities of airborne bacteria and fungi, including groups containing human and plant pathogens (mildew, smut and rust fungi, molds, Enterobacteriaceae, Pseudomonadaceae). In addition to detecting known bacterial and fungal IN (Pseudomonas sp., Fusarium sporotrichioides), we discovered two species of IN-active fungi that were not previously known as biological ice nucleators (Isaria farinosa and Acremonium implicatum). Our findings suggest that atmospheric bioaerosols, IN, and rainfall are more tightly coupled than previously assumed.
\end{abstract}

\section{Introduction}

Biological particles suspended in the atmosphere (bioaerosols) are key elements in the life cycle of many organisms and ecosystems, and they may influence the water cycle as cloud condensation and ice nuclei (IN) (Morris et al., 2008; Després et al., 2012). Laboratory studies have shown that certain species of bacteria, fungal spores, and pollen are highly efficient IN (Maki et al., 1974; Diehl et al., 2001; Morris et al., 2013), and bioparticles have been detected in clouds, fog, rain, and snowfall (Christner et al., 2008; Pratt et al., 2009). On a global scale bioaerosols may be only a minor fraction of the total IN population (Hoose et al., 2010; Sesartic et al., 2013), but regionally bioaerosols could play an important role in the evolution of clouds and precipitation (Möhler et al., 2007), especially in pristine regions like the Amazonian rainforest (Prenni et al., 2009; Pöschl et al., 2010; Pöhlker et al., 2012b).

So far, however, direct evidence linking bioaerosols with increases in IN, especially during and following 
precipitation, has been limited. For example, splash-induced emission of fungal spores during rain has been well documented (e.g., Hirst, 1953; and Allitt, 2000). Bigg and Miles (1964) observed a correlation between rainfall and IN concentrations when comparing extensive measurements in Australia, and Constantinidou et al. (1990) observed a downward flux of ice-active Pseudomonas syringae bacteria during rain. However, real-time measurements directly linking ambient bioaerosols and ice nuclei have been missing. Further, there is an apparent disconnect between concentrations of IN-active biological particles commonly found on vegetation and concentrations in the air above them. For example, Garcia et al. (2012) recently reported that variations in the number concentrations of airborne IN did not correlate with strong variations in the numbers of biological IN on underlying vegetation.

Airborne bioparticles are also major vectors for human, animal, and plant diseases (Pöschl, 2005; Després et al., 2012). Specifically, pollen and spores have been suggested to enhance asthma, allergies and other respiratory conditions during thundershowers (e.g., Packe and Ayres, 1985; Celenza et al., 1996; and Taylor and Jonsson, 2004; Denning et al., 2006; Dales et al., 2012), but the mechanism for this is not understood.

During the BEACHON-RoMBAS (Bio-hydro-atmosphere interactions of Energy, Aerosols, Carbon, $\mathrm{H}_{2} \mathrm{O}$, Organics, and Nitrogen - Rocky Mountain Biogenic Aerosol Study) intensive field campaign we performed comprehensive bioaerosol measurements during summertime in a semiarid North American pine forest (20 July to 23 August 2011). The biological, chemical and physical measurement techniques applied include online fluorescence detection (ultraviolet aerodynamic particle sizer, UV-APS; waveband integrated bioaerosol sensor, WIBS); scanning electron microscopy (SEM) and epifluorescence microscopy (FM); realtime IN counting in a continuous flow diffusion chamber (CFDC) and microscopic IN activation experiments; aerosol filter and impactor sampling; and DNA analysis for biological speciation. To our knowledge, this study provides the most comprehensive and detailed data set of time- and sizeresolved atmospheric bioaerosol properties available to date and is unique in the availability of comprehensive real-time and offline IN measurement data for comparison.

\section{Materials and methods}

\subsection{Site description}

BEACHON-RoMBAS brought together a large, interdisciplinary set of scientists to address issues surrounding the biogeochemical cycling of carbon and water at a location representative of the semi-arid western U.S (http://cires.colorado.edu/jimenez-group/wiki/ index.php/BEACHON-RoMBAS; http://web3.acd.ucar.edu/ beachon/). The measurements were located in a part of the Manitou Experimental Forest in a montane pine zone in the central Rocky Mountains $35 \mathrm{~km}$ northwest of Colorado Springs, Colorado, and $15 \mathrm{~km}$ north of Woodland Park, Colorado ( $2370 \mathrm{~m}$ elevation, lat. $39^{\circ} 6^{\prime} 0^{\prime \prime} \mathrm{N}$, long. $105^{\circ} 5^{\prime} 30^{\prime \prime} \mathrm{W}$ ). The forest canopy at the site is sparse and highly variable. Clusters of ponderosa pine trees approximately $10-20 \mathrm{~m}$ in height are separated by large open spaces of grass and forb understory. Grasses are generally $\sim 20 \mathrm{~cm}$ tall, with seed shocks occasionally reaching as high as $1 \mathrm{~m}$. The leaf area index (LAI) is also highly variable and was estimated to be a mean of approximately 1.9 (DiGangi et al., 2011), with trees covering $\sim 60 \%$ of the site.

Aerosol measurements were performed using inlets mounted 1-4 $\mathrm{m}$ above ground level, unless otherwise specified and as detailed below. Relative locations of samplers are shown in Fig. 1. During rain periods, all measurements discussed refer to particles not embedded in rain droplets. Below is a brief discussion of materials and methods of sampling and analysis utilized. Additional details are presented in the Supplement. The local time (LT) used for data analysis and plotting refers to Mountain Daylight Time (MDT). All times reported here are listed as LT.

\subsection{Meteorological and leaf moisture measurements}

Precipitation occurrence, rate, and microphysical state (i.e., rain versus hail) was measured using a laser-optical disdrometer (PARticle SIze and VELocity "PARSIVEL" sensor; OTT Hydromet GmbH, Kempton, Germany). The instrument senses a falling hydrometeor by measuring the magnitude and duration of attenuation of a temporally continuous 2-dimensional laser beam $(780 \mathrm{~nm})$ through which the hydrometeor passes. It, therefore, directly detects the presence of falling hydrometeors without the time delay of typical tipping bucket gauges and with greater particle size sensitivity than typical weighing gauges. The stated accuracy of liquid precipitation rate estimates is $\pm 5 \%$. Rainfall was measured in a clearing between tree clusters (Fig. 1) with a minimum of a $45^{\circ}$ sky view present at the precipitation monitoring sites. Therefore, summer precipitation measurements were not affected by the tree overstory. Additional under-canopy precipitation measurements were collected at the site, but are not discussed in this manuscript. Those measurements suggest that canopy interception within tree clusters is approximately $30 \%$ of the open area precipitation when aggregated over the entire warm season.

Leaf wetness state was characterized using a dielectric leaf wetness sensor (LWS; Decagon Devices, Inc., Pullman, $\mathrm{WA})$. The sensor provides a voltage $(\mathrm{mV})$ proportional to the amount of water or ice content on or near the sensor surface (within $\sim 1 \mathrm{~cm}$ ) by measuring the dielectric constant of the sensor. Attribution of the cause of wetness due to rain or dew formation (i.e., local condensation) is determined by comparing LWS voltage with optical precipitation measurements 
and by the pattern of voltage readings from the sensor. Sharp increases in the signal that are concurrent with precipitation events are characterized as "rainfall wetness" while slowly increasing values that are unaccompanied by precipitation events are characterized as dew formation. The LWS was deployed approximately $1 \mathrm{~m}$ above ground in a clearing next to the precipitation measurement sensor (Fig. 1).

Other meteorological parameters such as barometric pressure, air temperature, humidity, and wind speed and direction were measured using a WXT520 weather transmitter (Vaisala, Inc., Helsinki, Finland). The weather transmitter, the disdrometer, and the LWS were all located at the Manitou Experimental Forest observatory within $100 \mathrm{~m}$ of the rest of the particle measurements described below.

\subsection{Online fluorescence measurements}

An ultraviolet aerodynamic particle sizer (UV-APS; TSI Inc. Model 3314, St. Paul, MN) was utilized for this study following previously described procedures (Huffman et al., 2010, 2012). The instrument provides aerodynamic diameter $\left(D_{\mathrm{a}}\right)$ of aerosol particles in the range of $0.3-20 \mu \mathrm{m}$ and total fluorescence (420-575 nm; non-wavelength-dispersed) of particles after pulsed excitation by a Nd:YAG laser $\left(\lambda_{\text {ex }}=\right.$ $355 \mathrm{~nm}$ ). UV-APS number concentrations are reported here as integrated between 1 and $20 \mu \mathrm{m}$ in particle size. Smaller particles are transmitted within the instrument less efficiently and thus should be considered as lower limit values (Huffman et al., 2010). Measurements were initiated every $5 \mathrm{~min}$ and integrated over a sample length of $285 \mathrm{~s}$. Five-minute sample measurements were continuously repeated over a period of five weeks from 20 July to 23 August 2011 (35 days) and only briefly interrupted for maintenance procedures (usually less than $30 \mathrm{~min}$ per week). The UV-APS instrument sampled air through a total suspended particle (TSP) inlet head mounted $\sim 1.5 \mathrm{~m}$ above the roof of a metal trailer and $\sim 4 \mathrm{~m}$ above ground (inlet \#1), through a 0.75 inch tube under laminar flow conditions and into a climatecontrolled trailer at ground level. Inlets \#1-3 were mounted to vertical wooden beams and wrapped in reflective bubble wrap for heat insulation.

Also utilized was the waveband integrated bioaerosol sensor - model 4 (WIBS4; University of Hertfordshire, UK), a dual-channel fluorescence spectrometer providing size, asymmetry, and fluorescence of individual particles (Kaye et al., 2005; Foot et al., 2008; Gabey et al., 2010). Upon detection of a particle, xenon lamps provide two consecutive pulses of light at 280 and $370 \mathrm{~nm}$. The fluorescence of a particle is measured between 310 and $400 \mathrm{~nm}$ (the FL1 channel), and 400 and $600 \mathrm{~nm}$ (the FL2 channel). This leads to three separate fluorescence channels: FL1_280, FL2_280, and FL2_370. The forward scattering signal of the particle is also measured at four angular offsets using a quadrant photomultiplier tube, allowing for measurements of particle size and asymmetry. The WIBS4 was located on an automated
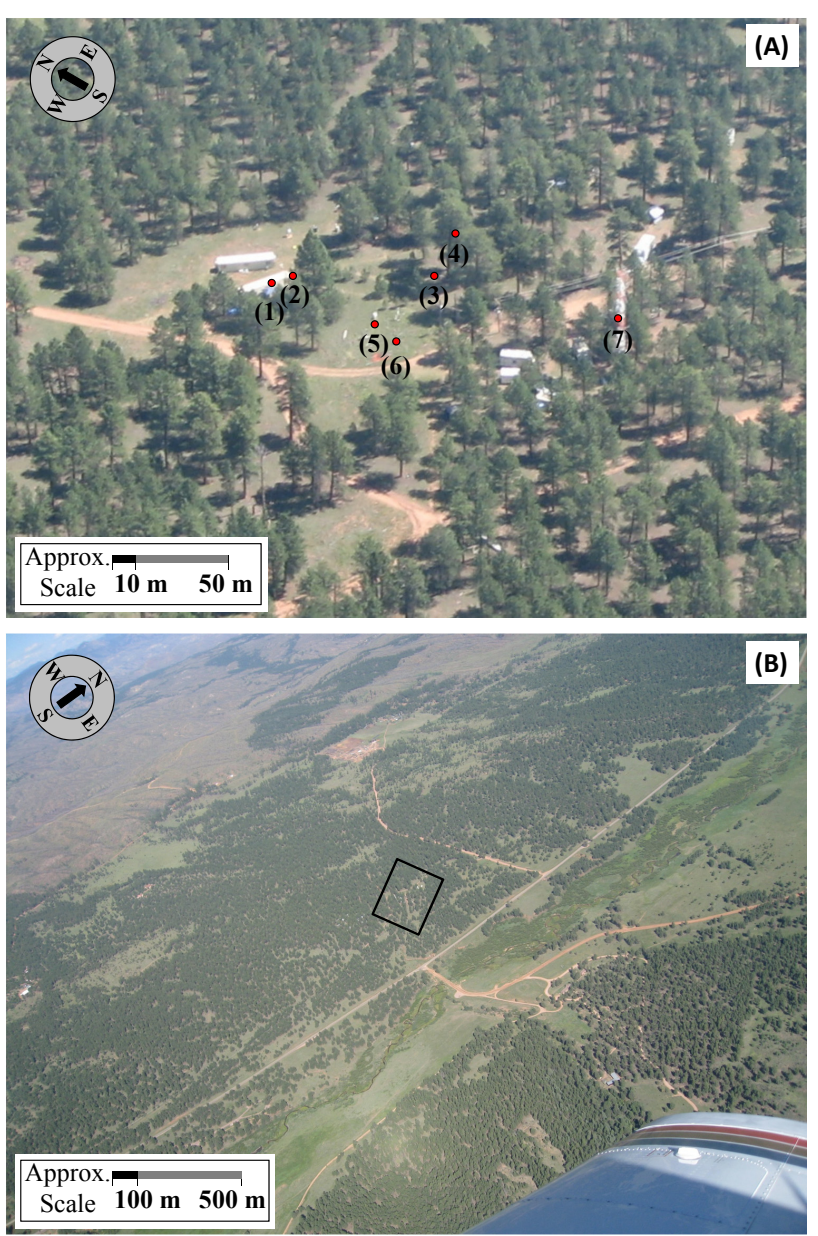

Fig. 1. Aerial photos of site layout. (A) Approximate lay-out of sampler and instruments: (1) Inlet \#4 [CFDC], (2) Inlets 1-3 [\#1: UV-APS, \#2: MOUDI, \#3: Total aerosol impactor + stacked filter unit], (3) Andersen biosamplers, (4) High-volume samplers, (5) Leaf wetness sensor (LWS), (6) Disdrometer, (7) WIBS profiling unit on Chemistry Tower. Instruments and samplers associated with inlets 1-4 are located inside trailer (white box). Additional details regarding other instrumentation and lay-out at: http://web3.acd. ucar.edu/beachon/site-info.shtml. (B) Aerial photo showing region immediately surrounding Manitou Experimental Forest sampling site, including county road 67 crossing north through the photo. Black box shows approximate area of photo (A). Photos courtesy: J. Patton.

profiling system running up the main measurement tower, which allowed profile measurements to be made between 3 and $22 \mathrm{~m}$. Profiles consisted of an eight stage upward profile, lasting around $45 \mathrm{~min}$, and a corresponding continuous downward profile, lasting about $3 \mathrm{~min}$. The WIBS4 total particle size distribution compared well with a co-sampling optical particle counter (OPC; Grimm Aerosol Technik Gmbh, Ainring, Germany), particularly in the super-micron regime.

A subset of the WIBS4 single particle data (8000 particles) was analyzed using hierarchical agglomerative cluster 
analysis using a group average distance metric (Robinson et al., 2013). The three minute WIBS4 descent profile data were split into several sections with height, and the gradient flux was calculated between each of these sections. Bioaerosol fluxes were then estimated for each cluster by combining the concentration gradient with vertical wind speed data using

$$
F=-0.16\left(\frac{\Delta z_{u} \Delta u}{\left(\ln \frac{z_{u 2}}{z_{u 1}}\right)^{2}}\right)\left(\frac{\Delta c}{\Delta Z_{\mathrm{c}}}\right),
$$

where $\Delta u$ is the difference between vertical wind speed measurements measured at heights $z_{u 1}$ and $z_{u 2}$ that are $\Delta z_{u}$ apart, and $\Delta c$ is the difference in concentrations between two heights that are $\Delta z_{\mathrm{c}}$ apart (Lindemann et al., 1982). Measurements within the canopy provide an upper limit for the role of biological IN in the region above the canopy.

Fluorescent particles $\left(N_{\mathrm{f}}\right)$ detected by the UV-APS and WIBS represent a lower limit for the abundance of primary biological aerosol particles (Huffman et al., 2010; Pöhlker et al., 2012a, 2013), probing fluorophores such as NAD(P)H, riboflavin, and tryptophan.

\subsection{Filter and impactor aerosol samples}

Coarse-mode particles were collected using a variety of filter and impactor sampling techniques from two adjacent inlets ( $4 \mathrm{~m}$ above ground), unless otherwise noted. Size-resolved particle samples were collected using a rotating micro-orifice uniform deposition impactor (MOUDI; MSP model 110-R, Shoreview, MN) at a flow-rate of $30 \mathrm{~L} \mathrm{~min}^{-1}$ via a dedicated inlet (\#2) identical to and $\sim 20 \mathrm{~cm}$ from UV-APS inlet \#1. Samples used for fluorescence microscopy were collected onto glass slides coated with a thin layer of high viscosity grease (Baysilone grease; Bayer, Germany) to reduce bounce, and samples used for offline ice nucleation analysis were collected onto uncoated siliconized, hydrophobic glass slides (Hampton Research, HR3-215, Aliso Viejo, CA). Size cuts at each plate and sample timing are listed in the SOM.

Total aerosol samples were collected onto glass cover slides $(13 \mathrm{~mm} \times 13 \mathrm{~mm})$ coated with the same grease coating described above and installed in a home-built, single-stage impactor (flow-rate $1.2 \mathrm{~L} \mathrm{~min}^{-1}, D_{50}$ cut $0.5 \mu \mathrm{m}$ ). Aerosol samples for electron microscopy analysis were collected with a stacked filter housing using $12 \mathrm{~mm}$ diameter gold-coated Nuclepore ${ }^{\circledR}$ polycarbonate filters with pore sizes of $2 \mu \mathrm{m}$ for coarse particles and $0.2 \mu \mathrm{m}$ for fine particles, respectively. The volume flow through the stacked filter unit was nominally $2.0 \mathrm{~L} \mathrm{~min}^{-1}$. Single-stage impactor and housing for Nuclepore ${ }^{\circledR}$ filters sub-sampled from a separate inlet (\#3) immediately next to and identical to inlets \#1 and \#2.

Total aerosol samples for DNA analysis were collected onto $150 \mathrm{~mm}$ glass fiber filters (Macherey-Nagel $\mathrm{GmbH}$, Type MN 85/90, 406015, Düren, Germany) using a selfstanding high-volume sampler (Digitel DHA-80) operated at
$1000 \mathrm{~L} \mathrm{~min}^{-1}$, placed at ground-level and located approximately $50 \mathrm{~m}$ from the sampling trailer. Filters were pre-baked at $500^{\circ} \mathrm{C}(12 \mathrm{~h})$ to remove any contaminant DNA and stored in pre-baked aluminum bags before and after sampling.

Size-resolved viable bioparticles were collected directly into growth media using an Andersen six-stage cascade impactor (Graseby Andersen; Atlanta, GA; $28 \mathrm{~L} \mathrm{~min}^{-1}$ ) for subsequent DNA analysis of viable organisms. Samplers were placed $\sim 2 \mathrm{~m}$ above ground on a section of wooden, diagonal-slat fencing that allowed air to pass through approx. $5 \mathrm{~cm} \times 5 \mathrm{~cm}$ holes in the support surface. The surfaces of samplers were sterilized with isopropyl alcohol before each period of collection to remove contaminant organisms. Samplers were operated separately for optimized collection of fungi and bacteria. Fungal growth medium (malt extract medium) was prepared according to Madelin (1994) with streptomycin (40 units, Sigma Aldrich) and ampicillin (20 units, Fisher Scientific). Bacterial growth medium (Luria Bertani medium; LB) was prepared according to Lighthart and Shaffer (1995) with cycloheximide (200 $\mu \mathrm{g} \mathrm{mL}^{-1}$, Sigma Aldrich). Samples for bacterial analysis were collected for $60 \mathrm{~min}$, and samples for fungal analysis were collected for $20 \mathrm{~min}$. Collection dishes were immediately removed from samplers after each use and placed in a temperature-controlled incubator (Amerex Instruments, IncuMax IC150R, Lafayette, CA) at $25^{\circ} \mathrm{C}$. Fungal colonies were incubated for $\sim 3$ days before counting and picked separately into $20 \mu \mathrm{L}$ of sterile water and into $150 \mu \mathrm{L}$ DPY medium (dextrose $10 \mathrm{gL}^{-1}$, peptone $3 \mathrm{gL}^{-1}$, yeast extract $0.3 \mathrm{~g} \mathrm{~L}^{-1}$ ). Bacterial colonies were incubated for $\sim 7$ days before counting and picking into sterile water. The picked colonies were lysed at $95^{\circ} \mathrm{C}$ for $10 \mathrm{~min}$ or tested for ice nucleation activity as described in Sect. 2.5.3. It is important to note that a given growth medium is only capable of culturing a small fraction $(<1-10 \%)$ of airborne fungal or bacterial species (e.g., Staley and Konopka, 1985; Lighthart, 2000; Bridge and Spooner, 2001; Fierer et al., 2008; and Després et al., 2012). Thus, results stemming from growth cultures presented here provide qualitative information for a subset of species possibly airborne at the site.

\subsection{Offline sample analysis}

\subsubsection{Microscopy}

Fluorescence microscopy images were taken on a BZ-9000 fluorescence microscope (Keyence, Inc., Osaka, Japan). The instrument was equipped with a super high-compression mercury lamp $(120 \mathrm{~W})$ and a $2 / 3$ inch, 1.5 megapixel monochrome CCD (charge-couple device). The following fluorescence filters were used to take images in different spectral ranges: OP-66834 DAPI-BP $\left(\lambda_{\text {ex }}=360 / 20 \mathrm{~nm}\right.$, $\left.\lambda_{\text {Dichroic }}=400 \mathrm{~nm}, \quad \lambda_{\text {Absorp }}=460 / 25 \mathrm{~nm}\right), \quad$ OP-66836 GFP-BP $\left(\lambda_{\mathrm{ex}}=470 / 20 \mathrm{~nm}, \lambda_{\text {Dichroic }}=495 \mathrm{~nm}, \lambda_{\text {Absorp }}=\right.$ $535 / 25 \mathrm{~nm}), \quad$ OP-66838 TexasRed $\left(\lambda_{\mathrm{ex}}=560 / 20 \mathrm{~nm}\right.$, 
$\left.\lambda_{\text {Dichroic }}=595 \mathrm{~nm}, \quad \lambda_{\text {Absorp }}=630 / 30 \mathrm{~nm}\right) . \quad$ Filter specifications are represented as wavelength and peak width $(\lambda /$ FWHM).

Scanning electron microscopy (SEM) images were acquired using the secondary electron in-lens detector of a high-performance field emission instrument (Zeiss, LEO 1530 FESEM, EHT $10 \mathrm{keV}$, WD $9 \mathrm{~mm}$ ). The elemental composition of inorganic components was characterized using the Oxford Instruments (Abington, UK) ultra-thin-window energy-dispersive X-ray (EDX) detector. Nuclepore ${ }^{\circledR}$ filter samples were scanned using a semi-automated spot counting technique (Sinha et al., 2008; Pöschl et al., 2010) at a magnification of $6500 \times($ pixel size $88.9 \mathrm{~nm}$ ) for coarse and $19500 \times$ (pixel size $29.6 \mathrm{~nm}$ ) for fine particle filters. Particles located on the predefined equidistant spots of the counting grid were automatically counted, and the recorded data were used to classify the particles according to size, composition, and mixing state. With spot counting, the probability for particles of a certain size and type to be counted is directly proportional to the 2-D surface area of the particles and the fraction of the filter surface covered by such particles. This relationship is used to upscale the counting results from the investigated filter area to the total filter area.

\subsubsection{DNA analysis}

Optimized methods of DNA extraction, amplification, and sequence analysis of the internal transcribed spacer (ITS) regions of genes were used to determine fungal diversity from the high-volume air filter samples (Fröhlich-Nowoisky et al., 2009, 2012). The primer pair ITS4Oo and ITS5 (Nikolcheva and Bärlocher, 2004) was used for amplification of Peronosporomycetes (formerly Oomycota). Also specific for this study, the ITS regions from fungal lysates, obtained from the cultivation experiments of Andersen impactor samples, were amplified with the primer pair ITS4 and ITS5 (White et al., 1990; Fröhlich-Nowoisky et al., 2009, 2012). The obtained PCR (polymerase chain reaction) products were sequenced using the primer ITS5 5 and sequence analysis was performed as described previously (Fröhlich-Nowoisky et al., 2009, 2012). Summarized fungal sequences were compared with known sequences using the Basic Local Alignment Search Tool (BLAST) at the National Center for Biotechnology (NCBI) and identified to the lowest taxonomic rank common to the top BLAST hits after chimeric sequences had been removed. Subsequently, sequences that produced the same BLAST results were pairwise aligned using the program BioEdit (version 7.1.3; Ibis Biosciences, Carlsbad, CA) and the similarity calculated using the PAM250 matrix. Sequences were grouped into operational taxonomic units (OTU) when their similarity was $>97 \%$. The sequences from the obtained operational taxonomic units have been deposited in the GenBank database under the following accession numbers: JX135610-JX136661 (fungi), and JQ976038JQ976273 (Peronosporomycetes).
For the determination of bacterial diversity from highvolume aerosol filter samples DNA was extracted as described by Després et al. (2007). The 16 S ribosomal gene was first amplified for taxonomic identification with primer pairs 9/27f and 1492r (Weisburg et al., 1991) with PCR conditions given by Després et al. (2007) and then cloned and sequenced. The same primer pair was used for the bacterial lysates obtained from Andersen sampler culture plates. For the bacterial sequences OTUs were identified using the mothur software package (Schloss et al., 2009) with chimeric sequences excluded using the Bellerophon program ( $\mathrm{Hu}-$ ber et al., 2004). Representative sequences of the OTUs were aligned using the multiple sequence comparison by log expectation (MUSCLE) package (Edgar, 2004) and thereafter manually checked. Sequence identification was based on phylogenetic analysis. Representative sequences were included as well as type species of various bacterial groups. Phylogenetic trees were based on a neighbor-joining algorithm based on Jukes Cantor corrected distances within the Phylip package (Felsenstein, 2005). Bacterial sequences have been deposited in the GenBank database under the following accession numbers: JX228219-JX228862.

Although PCR can theoretically lead to detection of as few as an individual molecule of DNA within a sample, actual results may be less efficient. Extraction and amplification scenarios have been tested previously (Fröhlich-Nowoisky et al., 2009, 2012), but specific fungal and bacterial DNA detection limits are not yet available.

\subsubsection{Culture freezing tests}

Fungal and bacterial colonies were picked from each sampler plate and cultured in $150 \mu \mathrm{L}$ DPY medium in 96-well polypropylene plates and incubated at $16^{\circ} \mathrm{C}$ for $13-40$ days (first test) and 62-82 days (second test). The intention was to pick select fungal colonies from the culturing media, but several bacterial colonies were picked unintentionally as well. Additionally, because only a few (2-10) colonies were picked as qualitative representatives from each original sample plate, quantification of IN number concentration by this method was not possible. A $50 \mu \mathrm{L}$ aliquot of DPY media containing hyphal fragments and fungal spores was tested from each well for ice nucleation activity in the temperature range -12 to $-2{ }^{\circ} \mathrm{C}$ (Garcia et al., 2012). Aliquots were transferred to a fresh, sterile, 96-well polypropylene PCR tray, and these were cooled in a thermal cycler (MJ Research, PTC200). Temperature variation across the head was $\pm 0.2{ }^{\circ} \mathrm{C}$ of the true temperature measured using a thermistor (Bio-Rad, VPT-0300, Hercules, CA). The cycler was programmed to descend in 0.5 or $1{ }^{\circ} \mathrm{C}$ increments to $-9.0^{\circ} \mathrm{C}$ (instrumental limit). After a 5 min dwell time at each temperature, the number of frozen wells was counted and the temperature lowered to the next level. Once at $-9^{\circ} \mathrm{C}$, the tray was transferred to a 96-well aluminum incubation block (VWR, 13259-260) which had been pre-cooled to $\sim-12^{\circ} \mathrm{C}$ inside a foam box in 
a freezer. The thermistor was inserted into a side well and after 10 min the block temperature and number of frozen wells was recorded. Aliquots of un-inoculated DPY medium were used as negative controls. Ice active isolates were then cultured on DPY agar and incubated at $16^{\circ} \mathrm{C}$ for $\sim 3-7$ days and tested again for ice nucleation activity. Mycelia were picked and placed into $50 \mu \mathrm{L}$ DPY (6 wells each) and tested as described above. Isolates were considered as positive only if they showed ice nucleation activity in all tests. Ice nucleation active isolates were also picked into $20 \mu \mathrm{L}$ water, lysed at $95^{\circ} \mathrm{C}$ for $10 \mathrm{~min}$, and identified by DNA analysis as described above.

\subsubsection{Microscopic IN activation}

Freezing properties of particles collected on hydrophobic MOUDI slides were determined with an optical microscope and a flow cell with temperature and relative humidity control (Dymarska et al., 2006; Iannone et al., 2011). The relative humidity (RH) was first set to $>100 \%$ to condense water droplets on the particles. The droplets were grown to approximately $100 \mu \mathrm{m}$ in diameter, and after droplet growth was completed each droplet contained between 30 and 100 particles. Then the temperature was decreased at a rate of $10 \mathrm{~K} \mathrm{~min}^{-1}$ until a temperature of $-40^{\circ} \mathrm{C}$ was reached. During the experiment, between 11 and 66 droplets (average 36 ) were continuously monitored with an optical microscope coupled to a CCD camera. Progression of ice formation was monitored and recorded continuously using a camera system.

The number of ice nuclei in a freezing experiment, \#IN(T), was calculated from the freezing data using the following equation (Vali, 1971):

$\# \mathrm{IN}(T)=-\ln \left(\frac{N_{\text {Total }}-N_{\text {Frozen }}(T)}{N_{\text {Total }}}\right) \times N_{\text {Total }}$,

where $N_{\text {Total }}$ is the total number of droplets in a freezing experiment and $N_{\text {Frozen }}(T)$ is the number of frozen droplets as a function of temperature in a freezing experiment. Equation (2) accounts for the fact that multiple IN can exist in the same droplet (Vali, 1971). The number of ice nuclei per volume of air as a function of temperature, $[\operatorname{IN}(T)]$, was calculated using the following equation:

$[\mathrm{IN}(T)]=\frac{\# \mathrm{IN}(T)}{\text { VolumeAirSampled }} \times \frac{\text { Area }_{\text {MOUDIStage }}}{\text { Area }_{\text {Monitored }}}$,

where "VolumeAirSampled" is the total volume of air sampled by the MOUDI, AreamoUDIStage is the total area covered by particles within a MOUDI stage and Area Monitored is the area monitored with the microscope. For Area MOUDIStage values were taken from Maenhuat et al. (1993) and Marple et al. (1991). Equation (3) assumes that particles are uniformly distributed over the MOUDI stages. Previous work by Maenhuat et al. (1993) has shown that this assumption is valid for stages $8-11$ at a resolution of two millimeters. For the other stages Maenhaut et al. (1993) noted the following variations in particle concentration density with location on the stage at a resolution of two millimeters: stage $7=+30 \% /-30 \%$, stage 5 and $6=+30 \% /-50 \%$, stage $4=+25 \% /-20 \%$, and stage $3=+40 \% /-20 \%$.

In the freezing experiments, a majority of the droplets froze by immersion freezing while a minority froze by contact freezing. Here immersion freezing refers to freezing of droplets by ice nuclei immersed in the liquid droplets, and contact freezing refers to freezing of liquid droplets by contact with neighboring frozen droplets (frozen droplets can grow by vapor transfer and eventually can come in contact with their neighbors). Droplets that froze by contact freezing were not considered when determining $N_{\text {Total }}$ and $N_{\text {Frozen }}(T)$ from the freezing data. In addition to immersion freezing and contact freezing, deposition freezing occasionally occurred in the freezing experiments. Here deposition freezing refers to freezing on a particle not immersed in a solution droplet. Deposition freezing was included in the calculations of $[\mathrm{IN}(T)]$ by adding the number of deposition freezing events to \#IN $(T)$ calculated with Eq. (2) above.

Depending on the experimental conditions, the maximum concentration of ice nuclei, $[\operatorname{IN}(T)]$, that can be detected for any given slide (i.e., size interval sampled with the MOUDI) with the microscope freezing technique is roughly $0.6-0.9 \mathrm{~L}^{-1}$ depending on the number of droplets condensed in an experiment and the total volume of air sampled by the MOUDI. As a result the maximum concentration of IN determined by the microscope technique is small compared to the maximum concentration determined with the CFDC method mentioned below.

\subsection{Real-time IN detection}

\subsubsection{IN analysis}

A ground-based version of the Colorado State University continuous flow diffusion chamber (CFDC) (Rogers et al., 2001) was employed for real-time measurements of IN concentrations. The CFDC permits observation of ice formation on a continuous stream of particles at controlled temperatures and humidities. In the CFDC, sampled air is directed vertically between two concentric ice-coated cylinders held at different temperatures, creating a zone supersaturated with respect to ice in the annular region. The sample air, $\sim 15 \%$ of the total flow, is injected between two particle-free sheath flows. As the particles in the sample flow are exposed to ice supersaturations for several seconds, those particles active as IN under the sample temperature and humidity conditions are nucleated and grown to ice crystals larger than a few $\mu \mathrm{m}$ in size. These larger particles are distinguished from small non-IN aerosols by an OPC at the outlet of the instrument. Physical impaction of larger particles $(>2.4 \mu \mathrm{m})$ in advance of the CFDC and reduction of humidity conditions to ice saturation in the lower third of the chamber prevents 
false detection of large particles as IN. We note that removing these larger particles upstream of the CFDC likely removes some particles that can potentially serve as IN; however, field data suggest that this underestimation is normally less than a factor of two under most sampling situations (Garcia et al., 2012). Temperatures $\left( \pm 1^{\circ} \mathrm{C}\right)$ and relative humidities $( \pm 3 \% \mathrm{RH}$ with respect to water; maximum uncertainty at $-30^{\circ} \mathrm{C}$ ) are well controlled in the instrument. For data used in this study, measurements were made at $-25^{\circ} \mathrm{C}$ at relative humidity in the range of 103 to $106 \%$ with respect to water. Under these conditions, the CFDC directly measures IN activating by condensation/immersion freezing (Sullivan et al., 2010), and contributions are expected to the IN population from both dust and biological particles (Prenni et al., 2009). For the CFDC data presented here, particle concentrations were enhanced upstream using an MSP Corporation (Model 4240) aerosol concentrator sampled from a dedicated inlet (\#4) mounted $\sim 1 \mathrm{~m}$ above ground level. Measurements made using the concentrator were corrected to ambient concentrations based on the manufacturer's specifications for $1 \mu \mathrm{m}$ particles, corrected slightly for the sampling conditions at Manitou, as determined from direct measurements made approximately every other day. IN number concentrations are reported at standard temperature and pressure (STP; $1 \mathrm{~atm}$ and $0{ }^{\circ} \mathrm{C}$ ).

\subsubsection{DNA analysis of IN samples}

Ice crystals activated as IN in the CFDC were collected via impaction at the CFDC outlet (Prenni et al., 2009; Garcia et al., 2012). Residual IN were impacted onto a glass slide, which was coated with $5 \mathrm{~mL}$ of molecular grade mineral oil (163-2129, Bio-Rad). DNA was then enzymatically extracted using proteinase K. The extracted DNA was PCR amplified using the universal $515 \mathrm{~F}$ and $1391 \mathrm{R}$ primers. The presence of biological IN was determined after PCR amplification via acrylamide gel electrophoresis. PCR products were cloned into a plasmid vector using the TOPO TA Cloning $\mathrm{Kit}^{\circledR}$ for sequencing (Invitrogen, Carlsbad, CA). Each clone was sequenced (Sanger method) and identified via BLAST search against the National Center for Biotechnology Information (NCBI) genome database.

\section{Results and discussion}

During the field campaign, we observed frequent transitions between dry background conditions and rain events. Figure 2 shows characteristic meteorological parameters and aerosol particle concentrations for seven consecutive days during the campaign (31 July to 6 August 2011). During dry periods we observed low concentrations of both fluorescent bioparticles $\left(N_{\mathrm{F}, \mathrm{c}} \approx 30 \mathrm{~L}^{-1}\right)$ and total aerosol particles $\left(N_{\mathrm{T}, \mathrm{c}} \approx 300 \mathrm{~L}^{-1}\right)$ in the supermicrometer size range, as detected by the UVAPS. At the onset of every rain event, the fluorescent biopar-

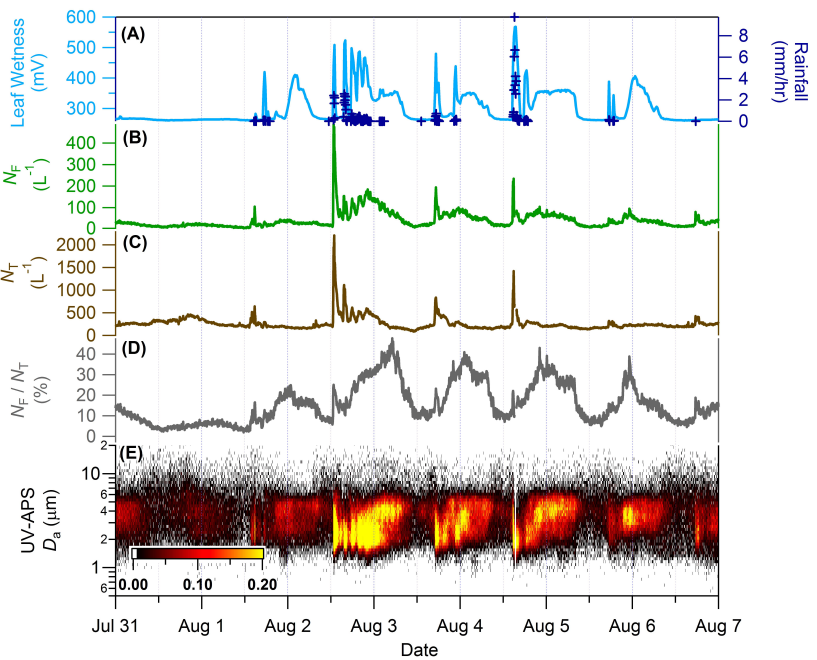

Fig. 2. Time series of measurement data showing repeated bursts of airborne biological particles with rain events. (A) Measured rainfall (dark blue crosses) and corresponding leaf wetness (light blue trace). (B) Concentrations $\left(\mathrm{L}^{-1}\right)$ of supermicron fluorescent bioparticles $\left(N_{\mathrm{F}}\right)$ and $(\mathbf{C})$ total $\left(N_{\mathrm{T}}\right)$ supermicron particles. (D) Fraction of fluorescent biological to total $\left(N_{\mathrm{F}} / N_{\mathrm{T}}\right)$. (E) Size-resolved fluorescent bioparticle concentrations measured with the UV-APS instrument (color bar: $\mathrm{d} N_{\mathrm{F}} / \mathrm{d} \log D_{\mathrm{A}}, \mathrm{L}^{-1}$ ). Data are plotted against local time (Mountain Daylight Time, MDT). Rain data shown for non-zero values.

ticles exhibited an immediate steep increase by as much as $60-160 \%$ per minute during the first ten minutes of precipitation (Fig. 2b). The total concentration of coarse particles ( $>1 \mu \mathrm{m}$ ), including non-fluorescent material, increased less dramatically but also substantially (by $10-65 \%$ per minute, Fig. 2c). In contrast to the expectation that the concentration of large aerosol particles would decrease during rainfall due to efficient removal mechanisms (e.g., precipitation scavenging), our online measurements show that the concentration of coarse aerosol particles not embedded in rain droplets can rapidly rise by factors as high as $\sim 4$ to $\sim 12$ and remain elevated over multiple hours, depending on the intensity and duration of the rain event. Heavy downpours produced a large and extended increase in particle concentration, but even light drizzle led to substantial enhancements (up to factor $\sim 4$ ). The strong increase of total and biological particle concentrations implies that the precipitation-related enhancements of particle sources as specified and discussed below were substantially stronger than the precipitation-related particle sinks (i.e., precipitation scavenging).

The number fraction of fluorescent bioparticles in total supermicron particles detected by the UV-APS was $\sim 2-6 \%$ under dry conditions (Fig. 2d). It jumped to $\sim 20 \%$ at the onset of rainfall, and it increased further to $\sim 40 \%$ when humid conditions with elevated leaf wetness persisted beyond the actual rainfall, which was mostly the case during nighttime after strong daytime precipitation (Fig. 2a). The UV-APS, 


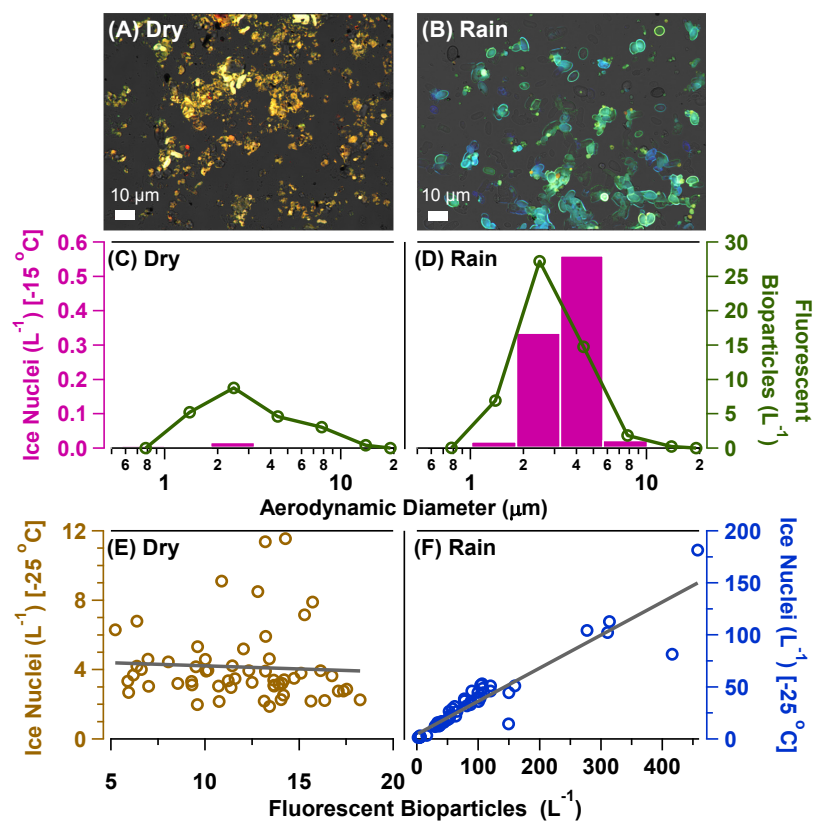

Fig. 3. Contrasting aerosol properties during dry periods and rain events. (A, B) Fluorescence microscope images of aerosol impactor samples. (C, D) Size distributions of ice nuclei observed at $-15^{\circ} \mathrm{C}$ in microscopic IN activation experiments (bars, left axis) and of fluorescent bioparticles detected by UV-APS (traces, right axis). (E, F) Number concentrations of ice nuclei observed at $-25^{\circ} \mathrm{C}$ in CFDC measurements plotted against fluorescent bioparticles detected by UV-APS (particle diameter $<2.4 \mu \mathrm{m}$ ). The displayed linear fits yield $R^{2}$ correlation coefficients of (E) 0.003 and (F) 0.88 .

however, provides only a lower limit proxy for the overall abundance of bioparticles, because it was designed for online detection of viable bacteria with strong autofluorescence at specific wavelengths (Huffman et al., 2012; Pöhlker et al., 2012a). Microscopic investigations, making use of a wider range of wavelengths as well as morphological characteristics and elemental composition data (FM, SEM), indicate that the relative abundance of bioparticles in the supermicron size range during rain events (i.e., during or after rainfall) was as high as 55-80\%. In contrast, mineral dust particles prevailed during dry periods (70-80\%, Tables 1-2). Figure $3 \mathrm{a}$ and $\mathrm{b}$ show microscopic images of aerosol impactor samples clearly highlighting the contrast between the relatively weak red fluorescence from irregularly shaped dust in a sample collected during dry weather (Bozlee et al., 2005) and the intense green and blue fluorescence from cellular structures in a sample collected during a rain event.

During rainfall the median diameter of fluorescent bioparticles was usually $2-3 \mu \mathrm{m}$, and the concentration of these particles decayed swiftly after the precipitation had stopped (Fig. 2e). When humid conditions with elevated leaf wetness persisted beyond the actual precipitation, larger fluorescent bioparticles with a median diameter around 4-6 $\mu \mathrm{m}$ appeared ca. $8 \mathrm{~h}$ after the beginning of rainfall and persisted
Table 1. Number fraction of biological particles and mineral dust particles in aerosol samples collected during dry periods and rain events. The sample numbers S10, S12, S20, S23 refer to Nuclepore ${ }^{\circledR}$ filters analyzed by SEM (details specified in Sect. S1.4.1.3). The UV-APS data were averaged over periods matching the filter sample collection times. Fluorescent biological aerosol particles (FBAP), primary biological aerosol particles (PBAP).

\begin{tabular}{lcc|cc}
\hline Method (Particles) & \multicolumn{2}{c|}{ Dry } & \multicolumn{2}{c}{ Rain } \\
\cline { 2 - 5 } & S10 & S12 & S20 & S23 \\
\hline UV-APS (FBAP/Total) & 0.04 & 0.06 & 0.28 & 0.20 \\
SEM (PBAP/Total) & 0.03 & 0.07 & 0.78 & 0.56 \\
SEM (Dust/Total) & 0.80 & 0.76 & 0.08 & 0.38 \\
\hline
\end{tabular}

for up to 12 more hours (Fig. 2e). Statistical cluster analysis of the size, asymmetry, and multi-channel fluorescence data recorded with the WIBS instrument confirmed that the smaller bioparticles enhanced during rainfall were qualitatively different from the larger ones enhanced after rainfall, implying different sources or physiological states (Pöhlker et al., 2012a; Robinson et al., 2013).

The $2-3 \mu \mathrm{m}$ bioparticles present throughout the rainfall are likely bacteria or fungal spores released from surrounding vegetation surfaces through mechanical agitation by raindrops (Faulwetter, 1917; Hirst, 1953; Hirst and Stedman, 1963; Butterworth and McCartney, 1991; Madden, 1997; Huber et al., 1998; Allitt, 2000; Paul et al., 2004; Boyer, 2008), which is consistent with the observed strong initial enhancement at the onset of rain and a less pronounced enhancement during continued rainfall and immediately following events (e.g., 2 August, Fig. $2 \mathrm{a}-\mathrm{c}$ ). The process of rain splash emission has been well documented and is the most likely source of bioparticles observed. Several theories have been suggested to explain the micro-scale dynamics involved (Hirst and Stedman, 1963; Leach, 1976; Allitt, 2000). The increase of relative humidity and leaf wetness can also trigger other bioparticle emission mechanisms like the active wet ejection of fungal spores (Hirst and Stedman, 1963; Elbert et al., 2007; Després et al., 2012) or hygroscopic swellinginduced pollen fragmentation (Taylor et al., 2004; Miguel et al., 2006; Augustin et al., 2012; Pummer et al., 2012). Moreover, bioparticles observed during rainfall may also have precipitated from clouds in which some of them served either as giant cloud condensation nuclei (GCCN) or ice nuclei contributing to rain formation (Sands et al., 1982; Morris et al., 2004; Christner et al., 2008).

The 4-6 $\mu \mathrm{m}$ bioparticles observed during the humid postrain periods appear to have been freshly emitted from active biota growing on wetted terrestrial surfaces near the measurement location, e.g., spores ejected by fungi, lichens and other cryptogamic covers growing on soil, rock and vegetation (Elbert et al., 2007, 2012). The attribution of the larger 
Table 2. Number fraction of bioparticles on MOUDI stages 4 (3.2$5.6 \mu \mathrm{m})$ and $5(1.8-3.2 \mu \mathrm{m})$ of aerosol samples collected during a dry period (M28) and a rain event (M10). See SOM Sect. S1.4.1.1 for sampling dates. Estimates based on fluorescence microscopy.

\begin{tabular}{ccc|cc}
\hline & \multicolumn{2}{c}{ Dry (M28) } & \multicolumn{2}{c}{ Rain (M10) } \\
\cline { 2 - 5 } & Stage 4 & Stage 5 & Stage 4 & Stage 5 \\
\hline Number fraction & 0.25 & 0.22 & 0.79 & 0.67 \\
\hline
\end{tabular}

post-rain bioparticles to local sources is consistent with colocated concentration gradient measurements suggesting a net upward flux of fluorescent bioparticle emission after rainfall $\left(\sim 50-500 \mathrm{~m}^{-2} \mathrm{~s}^{-1}\right)$, in range with earlier estimates of bioparticle emission fluxes (Lindemann et al., 1982; Elbert et al., 2007; Burrows et al., 2009; Després et al., 2012).

DNA analyses of aerosol samples collected during the campaign yielded over 5000 sequences that could be attributed to $\sim 1000$ different operational taxonomic units, or species of bacteria, fungi, and other organisms. The species richness and the frequency of occurrence of both bacteria and fungi were higher by factors of 2-10 in aerosol samples collected under wet conditions (periods including rainfall or humid post-rain periods) than under dry conditions. Similar to other rural continental regions, most bacterial species were from Proteobacteria, Actinobacteria, Firmicutes and Bacteroidetes (Després et al., 2012). Most fungal species were from Basidiomycota (club fungi) and Ascomycota (sac fungi) (Fröhlich-Nowoisky et al., 2009, 2012). The identified groups of microorganisms comprise a number of plant pathogens and human allergens (mildew, smut and rust fungi, molds, Enterobacteriaceae, Pseudomonadaceae), though not all species within these groups exhibit pathogenic or allergenic properties. These findings provide a possible rationale for reported enhancements of asthma and other respiratory diseases during rain showers (Taylor and Jonsson, 2004; Dales et al., 2012). Follow-up studies will be necessary to investigate the possible relationships and mechanisms on a species level.

To characterize the ice nucleating ability of aerosol particles during rain events and dry periods, we present CFDC real-time measurements of IN activity at $-25^{\circ} \mathrm{C}$ for particles $<2.4 \mu \mathrm{m}$, as well as microscopic IN activation experiments of samples collected with a cascade impactor resolving a size range of $0.3-18 \mu \mathrm{m}$ and a temperature range of -10 to $-40^{\circ} \mathrm{C}$. During rain events, the IN concentrations measured in the CFDC were an order of magnitude higher than during dry periods and followed a close linear correlation with fluorescent bioparticle concentration that was not observed under dry conditions (Fig. 3e vs. f) (Prenni et al., 2013; Tobo et al., 2013). The microscopic experiments showed that for rain events, the concentration of IN at relatively warm temperatures $\left(-15^{\circ} \mathrm{C}\right)$ was $\geq 0.79 \mathrm{~L}^{-1}$, and these warm-temperature IN had sizes around 1.8-5.6 $\mu \mathrm{m}$ (Figs. 4, 5), which is com-

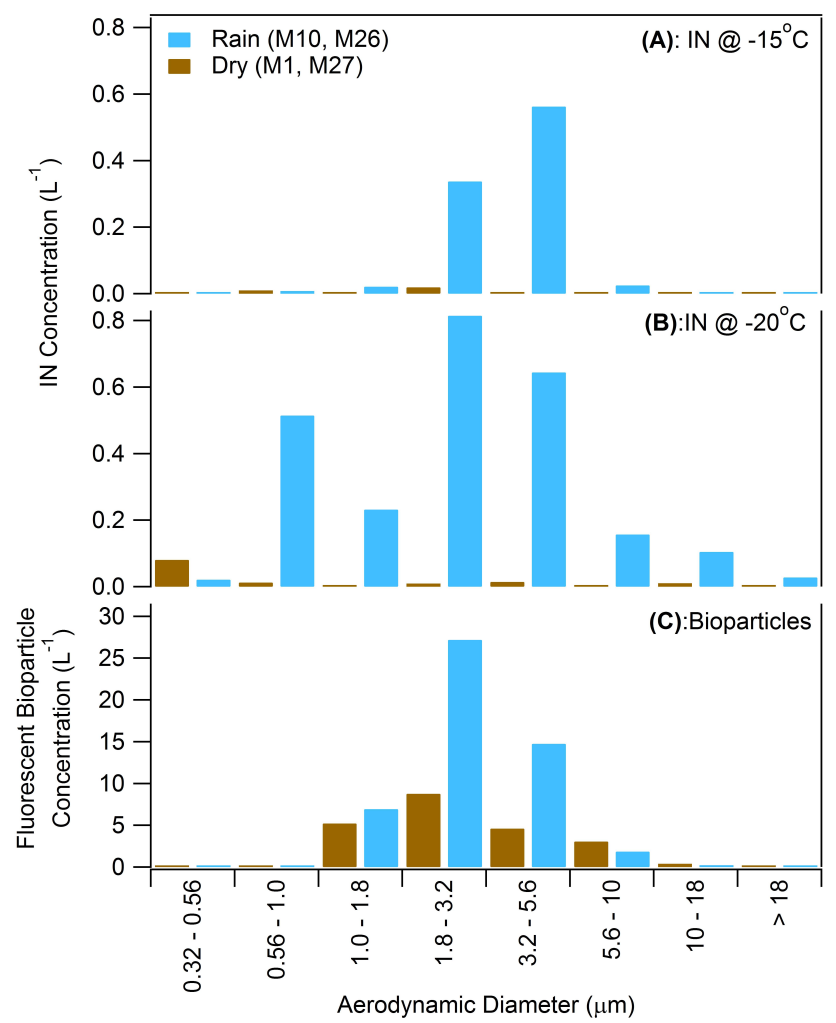

Fig. 4. Size distributions of ice nuclei observed in microscopic IN activation experiments (A) at $-15^{\circ} \mathrm{C}$ and (B) at $-20^{\circ} \mathrm{C}$ for aerosol impactor samples collected during dry periods and rain events. (C) Size distribution of bioparticles measured by UV-APS during the same periods. See SOM Sect. S1.4.1.1 for sampling dates.

mon for biological ice nucleators such as bacteria and fungal spores. In addition, during these wet periods as much as $\sim 1 \%$ of supermicron particles were IN active at $-15^{\circ} \mathrm{C}$ (Fig. 6). In contrast, during dry weather conditions dominated by dust the concentrations of IN at $-15^{\circ} \mathrm{C}$ were between 0.01 and $0.02 \mathrm{~L}^{-1}$, and a relationship between size and IN concentration was not obvious at either -15 or $-20^{\circ} \mathrm{C}$ (Figs. 4, 5). During the dry events the fraction of supermicron particles IN active at $-15^{\circ} \mathrm{C}$ was much lower $\left(<10^{-4}\right)$, as expected for mineral dust (Möhler et al., 2006; Connolly et al., 2009; DeMott et al., 2011; Hoose and Mohler, 2012).

The size distribution of IN that activated at $-15^{\circ} \mathrm{C}$ exhibits a distinct peak in the range $2-6 \mu \mathrm{m}$ that coincides with the peak of the size distribution of fluorescent bioparticles observed during rain events (Fig. 3d). The correlations between IN and FBAP (fluorescent biological aerosol particle) number concentrations and size distributions (Fig. 3d, f), as well as the temperature dependence of IN activation (Figs. 4, 5), suggest that bioparticles account for the observed increase of IN during rain and that both the $2-3 \mu \mathrm{m}$ particle mode directly associated with rainfall and the $4-6 \mu \mathrm{m}$ particle mode associated with humid post-rain periods comprise highly efficient IN. Indeed, IN-active bacteria of the genus 


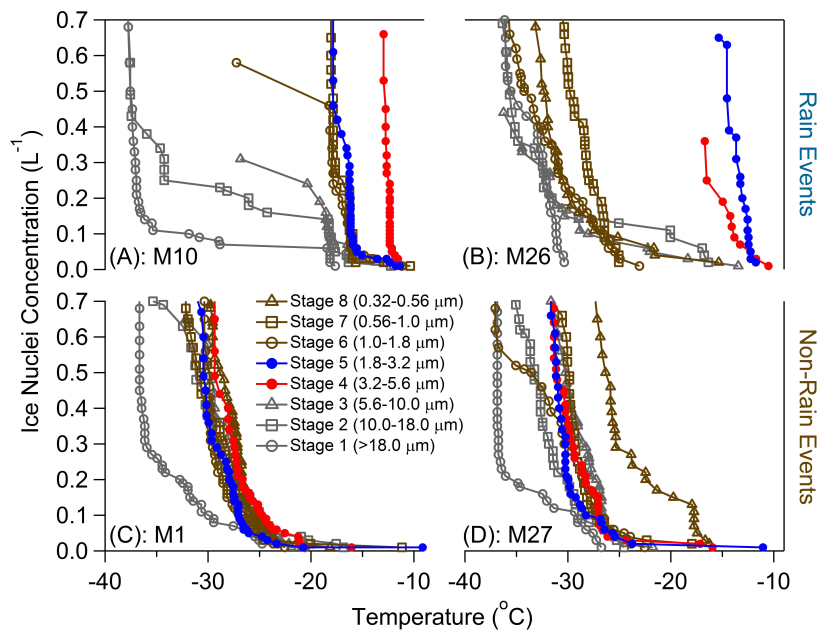

Fig. 5. IN activation curves from microscopic IN activation experiments with size-resolved aerosol samples (MOUDI stages). Upper panels (A, B) for samples collected during rain events, and lower panels $(\mathbf{C}, \mathbf{D})$ for samples collected during dry periods. Red traces show Stage $4(3.2-5.6 \mu \mathrm{m})$, blue traces show Stage $5(1.8-3.2 \mu \mathrm{m})$, brown traces show Stages 6-8, and gray traces show Stages 1-3. See SOM Sect. S1.4.1.1 for sampling dates.

Pseudomonas sp., known to have activation temperatures up to $-4{ }^{\circ} \mathrm{C}$ (Morris et al., 2004), were found by the combination of cultivation experiments, freezing tests, and DNA analyses of aerosol samples in the size range of $\sim 1-4 \mu \mathrm{m}$. Using DNA analysis we also found the fungal species Fusarium sporotrichioides, which is known to be IN active at -10 to $-8{ }^{\circ} \mathrm{C}$ (Richard et al., 1996), and two previously unknown IN-active fungi from the phylum of Ascomycota: Isaria farinosa and Acremonium implicatum (Fig. 7). The IN-active fungi were cultivated and produced spores that are fluorescent and exhibit diameters in the range of $1-4 \mu \mathrm{m}$. A mixture of the cultivated spores and mycelia induce freezing at -12 to $-5^{\circ} \mathrm{C}$. Overall, the DNA analyses of aerosol samples collected during rain events showed higher diversity and frequency of occurrence for bacteria and fungi from groups that comprise IN-active species (Pseudomonadaceae; Sordariomycetes).

Identification of both Pseudomonas sp. and Sordariomycetes directly from activated IN samples collected using the CFDC during rain shows conclusively that the biological particles were indeed active as ice nuclei. Convective lofting of biological IN active at temperatures of $-15^{\circ} \mathrm{C}$ and warmer, where ice mass growth rates maximize (Korolev, 2007) and freezing of larger drops can initiate secondary ice generation (Hallett and Mossop, 1974), may invigorate the glaciation of mixed-phase clouds and thus may strongly contribute to the formation of precipitation.

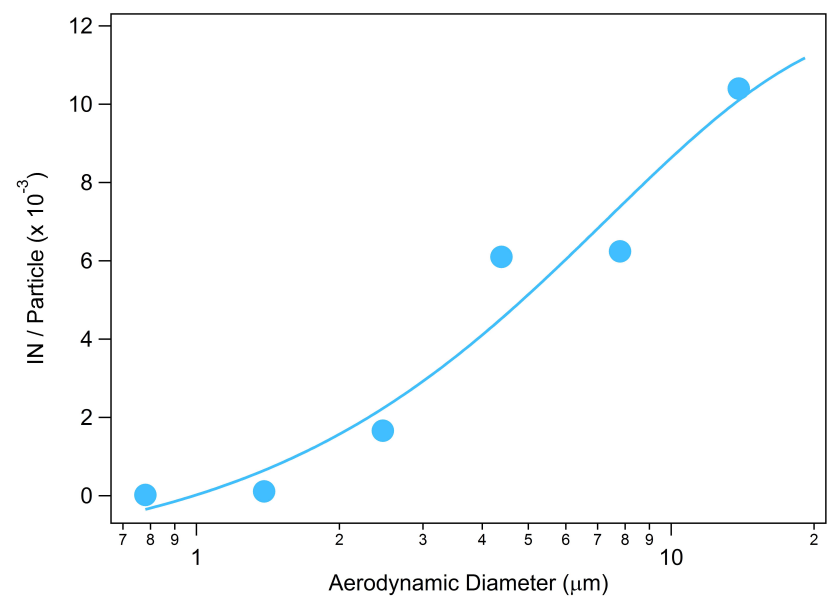

Fig. 6. An estimate of the fraction of particles collected during rain events (M10, M26) that can serve as IN at $-15^{\circ} \mathrm{C}$. IN concentrations were calculated from microscopic IN activation experiments and particle concentrations were calculated from UV-APS measurements. See SOM Sect. S1.4.1.1 for sampling dates. Note that the fraction of particles with IN activity is greater than 1 in 1000 for all particles $>2 \mu \mathrm{m}$ and exceeds 1 in 100 for particles $>10 \mu \mathrm{m}$. Exponential curve shown to guide the eye.

\section{Conclusions}

Our observations indicate that rainfall can trigger intense bursts of bioparticle emission within the forest canopy and massive enhancements of atmospheric bioaerosol concentrations by an order of magnitude or more, from the onset of precipitation through extended periods of high surface wetness after the rainfall (up to one day). The strong contrast against low background concentrations under dry conditions suggests that the repeated bursts of bioparticle release during and after rain may play an important role in the spread and reproduction of microorganisms in certain environments (e.g., Hirst and Stedman, 1963; Fitt et al., 1989; Constantinidou et al., 1990; and Paul et al., 2004), and may also contribute to the atmospheric transmission of pathogenic and allergenic agents (Fig. S1). To quantify these effects, we suggest comprehensive metagenomic analyses and dispersion studies of atmospheric bioaerosols contrasting different meteorological conditions. Follow-up studies in other environments shall elucidate whether the observed rain-related bioaerosol increase is a common feature of terrestrial ecosystems or specific for the investigated semi-arid environment.

Three key results of our measurements during rain and dry periods indicate the critical and dynamic role of bioaerosols as IN sources that may strongly influence the evolution of cloud microphysics and precipitation processes: (1) large and closely correlated increases of bioparticles and IN during rain events; (2) similar size distribution patterns of rain-enhanced bioparticles and IN active in the warmest regime of mixedphase clouds $\left(\geq-15^{\circ} \mathrm{C}\right)$; and (3) identification of IN-active 

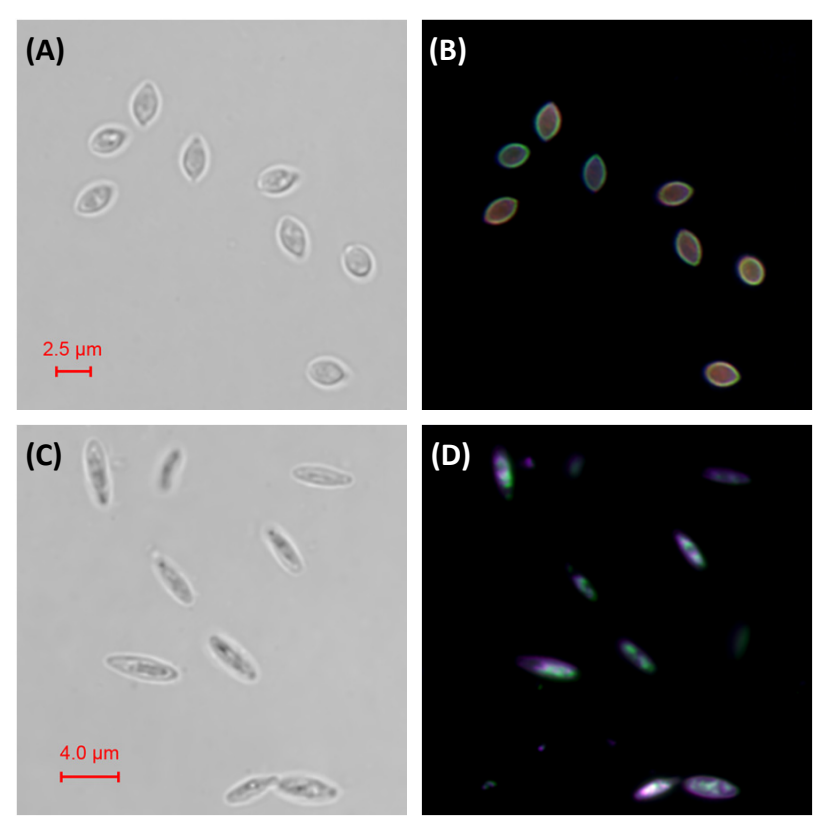

Fig. 7. Fluorescence microscopy images of fungal spores from lab cultivation of the two fungi (Ascomycota) with previously unknown IN activity: (A-B) Isaria farinosa, (C-D) Acremonium implicatum. Left panels show bright-field image and right panels show overlay of red, green, and blue fluorescence.

bioparticles in aerosol and IN samples collected during rain events. Rainfall that triggers bioparticle emission may seed further precipitation (Bigg and Miles, 1964) by convective lifting of bioparticles into clouds where they can serve as IN, inducing cold rain formation (Hallett and Mossop, 1974; Korolev, 2007), or as GCCN, inducing warm rain formation (Möhler et al., 2007; Pöschl et al., 2010; Després et al., 2012). However, more detailed vertical transport and vertical profile information about rain-related effects will be critical to understanding what the impact of rain-initiated bioaerosol production could mean at the cloud level and for cloud formation. Recent studies suggested that bioaerosols play crucial roles in the hydrological cycle and evolution of pristine tropical rainforest ecosystems (Prenni et al., 2009; Pöschl et al., 2010; Pöhlker et al., 2012b). The measurement results of this study suggest that bioaerosols may also play an important role in midlatitude semi-arid forest ecosystems (Schumacher et al., 2013), consistent with the recent observation that biogenic emissions significantly impact $\mathrm{CCN}$ in the region (Levin et al., 2012). Accordingly, deforestation and changes in land use and biodiversity might have a significant influence on the abundance of IN, the microphysics and dynamics of clouds and precipitation in these regions, and thus on regional and global climate (DeMott et al., 2010). In-cloud measurements of aerosol and hydrometeor composition, aerosol- and cloud-resolving process model studies, and earth system model studies capturing potential feedbacks between the atmosphere and biosphere will be required to further quantify the relevance of these effects for climate prediction.

\section{Supplementary material related to this article is available online at: http://www.atmos-chem-phys.net/13/ 6151/2013/acp-13-6151-2013-supplement.pdf.}

Acknowledgements. The BEACHON-RoMBAS campaign was partially supported by an ETBC (Emerging Topics in Biogeochemical Cycles) grant to the National Center for Atmospheric Research (NCAR), the University of Colorado, Colorado State University, and Penn State University (NSF ATM-0919189). J. A. Huffman acknowledges internal faculty funding from the University of Denver. The Mainz team acknowledges financial support from the Max Planck Society (MPG), the Max Planck Graduate Center with the Johannes Gutenberg University Mainz (MPGC), the Geocycles Cluster Mainz (LEC Rheinland-Pfalz), and the German Research Foundation (DFG PO1013/5-1, FOR 1525 INUIT). R. H. Mason and A. K. Bertram acknowledge financial support from the the National Sciences and Engineering Research Council of Canada. Y. Tobo acknowledges the Japanese Society for the Promotion of Science (JSPS) Postdoctoral Fellowships for Research Abroad. CFDC measurements and analysis were funded by NSF (ATM-0919042, AGS-1036028). J. L. Jimenez and D. A. Day acknowledge U.S. DOE (BER, ASR program) DE-SC0006035. N. H. Robinson and M. Gallagher thank Defence Science and Technology Laboratory (DSTL) for loan of WIBS-4 instrument. The authors wish to thank: the USFS, NCAR, R. Oakes, A. Guenther, and J. Smith for providing logistical support and access to the Manitou Experimental Forest field site; A. Turnipseed for providing meteorological data; A. Sun for help with ice nucleation microscopy measurements; W. Elbert for useful discussions; J. D. Förster, T. C. J. Hill, S. Lelieveld, T. Pooya, and M. G. Grant for technical assistance in bioaerosol analysis.

The service charges for this open access publication have been covered by the Max Planck Society.

Edited by: A. Laaksonen

\section{References}

Allitt, U.: Airborne fungal spores and the thunderstorms of 24 June 1994, Aerobiologia, 16, 397-406, 2000.

Augustin, S., Hartmann, S., Pummer, B., Grothe, H., Niedermeier, D., Clauss, T., Voigtländer, J., Tomsche, L., Wex, H., and Stratmann, F.: Immersion freezing of birch pollen washing water, Atmos. Chem. Phys. Discuss., 12, 32911-32943, doi:10.5194/acpd-12-32911-2012, 2012.

Bigg, E. K. and Miles, G. T.: The Results of Large-Scale Measurements of Natural Ice Nuclei, J. Atmos. Sci., 21, 396403, doi:10.1175/1520-0469(1964)021<0396:trolmo>2.0.co;2, 1964. 
Boyer, D. G.: Fecal coliform dispersal by rain splash on slopes, Agr. Forest Meteorol., 148, 1395-1400, doi:10.1016/j.agrformet.2008.04.001, 2008.

Bozlee, B. J., Misra, A. K., Sharma, S. K., and Ingram, M.: Remote Raman and fluorescence studies of mineral samples, Spectrochimica Acta Part a-Molecular and Biomolecular Spectroscopy, 61, 2342-2348, doi:10.1016/j.saa.2005.02.033, 2005.

Bridge, P. and Spooner, B.: Soil fungi: diversity and detection, Plant Soil, 232, 147-154, 2001.

Burrows, S. M., Butler, T., Jöckel, P., Tost, H., Kerkweg, A., Pöschl, U., and Lawrence, M. G.: Bacteria in the global atmosphere - Part 2: Modeling of emissions and transport between different ecosystems, Atmos. Chem. Phys., 9, 9281-9297, doi:10.5194/acp-9-9281-2009, 2009.

Butterworth, J. and McCartney, H. A.: The disperal of bacteria from leaf surfaces by water splash, Journal of Applied Bacteriology, 71, 484-496, doi:10.1111/j.1365-2672.1991.tb03822.x, 1991.

Celenza, A., Fothergill, J., Kupek, E., and Shaw, R. J.: Thunderstorm associated asthma: A detailed analysis of environmental factors, British Medical Journal, 312, 604-607, 1996.

Christner, B. C., Morris, C. E., Foreman, C. M., Cai, R. M., and Sands, D. C.: Ubiquity of biological ice nucleators in snowfall, Science, 319, 1214-1214, doi:10.1126/science.1149757, 2008.

Connolly, P. J., Möhler, O., Field, P. R., Saathoff, H., Burgess, R., Choularton, T., and Gallagher, M.: Studies of heterogeneous freezing by three different desert dust samples, Atmos. Chem. Phys., 9, 2805-2824, doi:10.5194/acp-9-2805-2009, 2009.

Constantinidou, H. A., Hirano, S. S., Baker, L. S., and Upper, C. D.: Atmospheric dispersal of ice nucleation-active bacteria - the role of rain, Phytopathology, 80, 934-937, doi:10.1094/Phyto80-934, 1990.

Dales, R. E., Cakmak, S., Judek, S., Dann, T., Coates, F., Brook, J. R., and Burnett, R. T.: The role of fungal spores in thunderstorm asthma, Chest, 123, 745-750, doi:10.1378/chest.123.3.745, 2012.

DeMott, P. J., Prenni, A. J., Liu, X., Kreidenweis, S. M., Petters, M. D., Twohy, C. H., Richardson, M. S., Eidhammer, T., and Rogers, D. C.: Predicting global atmospheric ice nuclei distributions and their impacts on climate, P. Natl. Acad. Sci., 107, 11217-11222, doi:10.1073/pnas.0910818107, 2010.

DeMott, P. J., Möhler, O., Stetzer, O., Vali, G., Levin, Z., Petters, M. D., Murakami, M., Leisner, T., Bundke, U., Klein, H., Kanji, Z. A., Cotton, R., Jones, H., Benz, S., Brinkmann, M., Rzesanke, D., Saathoff, H., Nicolet, M., Saito, A., Nillius, B., Bingemer, H., Abbatt, J., Ardon, K., Ganor, E., Georgakopoulos, D. G., and Saunders, C.: Resurgence in ice nuclei measurement research, B. Am. Meteorol. Soc., 92, 1623-1635, 2011.

Denning, D. W., O'Driscoll, B. R., Hogaboam, C. M., Bowyer, P., and Niven, R. M.: The link between fungi and severe asthma: a summary of the evidence, European Respiratory Journal, 27, 615-626, doi:10.1183/09031936.06.00074705, 2006.

Després, V. R., Nowoisky, J. F., Klose, M., Conrad, R., Andreae, M. O., and Pöschl, U.: Characterization of primary biogenic aerosol particles in urban, rural, and high-alpine air by DNA sequence and restriction fragment analysis of ribosomal RNA genes, Biogeosciences, 4, 1127-1141, doi:10.5194/bg-4-1127-2007, 2007.

Després, V. R., Huffman, J. A., Burrows, S. M., Hoose, C., Safatov, A. S., Buryak, G. A., Fröhlich-Nowoisky, J., Elbert, W., Andreae, M. O., Pöschl, U., and Jaenicke, R.: Primary Biological
Aerosol Particles in the Atmosphere: A Review, Tellus B, 64, 15598, doi:10.3402/tellusb.v64i0.15598, 2012.

Diehl, K., Quick, C., Matthias-Maser, S., Mitra, S. K., and Jaenicke, R.: The ice nucleating ability of pollen - Part I: Laboratory studies in deposition and condensation freezing modes, Atmos. Res., 58, 75-87, 2001.

DiGangi, J. P., Boyle, E. S., Karl, T., Harley, P., Turnipseed, A., Kim, S., Cantrell, C., Maudlin III, R. L., Zheng, W., Flocke, F., Hall, S. R., Ullmann, K., Nakashima, Y., Paul, J. B., Wolfe, G. M., Desai, A. R., Kajii, Y., Guenther, A., and Keutsch, F. N.: First direct measurements of formaldehyde flux via eddy covariance: implications for missing in-canopy formaldehyde sources, Atmos. Chem. Phys., 11, 10565-10578, doi:10.5194/acp-1110565-2011, 2011.

Dymarska, M., Murray, B. J., Sun, L. M., Eastwood, M. L., Knopf, D. A., and Bertram, A. K.: Deposition ice nucleation on soot at temperatures relevant for the lower troposphere, J. Geophys. Res.-Atmos., 111, D04204, doi:10.1029/2005jd006627, 2006.

Edgar, R.: MUSCLE: a multiple sequence alignment method with reduced time and space complexity, BMC Bioinformatics, 5, 113, 2004.

Elbert, W., Taylor, P. E., Andreae, M. O., and Pöschl, U.: Contribution of fungi to primary biogenic aerosols in the atmosphere: wet and dry discharged spores, carbohydrates, and inorganic ions, Atmos. Chem. Phys., 7, 4569-4588, doi:10.5194/acp-7-4569-2007, 2007.

Elbert, W., Weber, B., Burrows, S., Steinkamp, J., Budel, B., Andreae, M. O., and Pöschl, U.: Contribution of cryptogamic covers to the global cycles of carbon and nitrogen, Nature Geosci., 5, 459-462, doi:10.1038/ngeo1486, 2012.

Faulwetter, R. C.: Wind-blown rain, a factor in disease dissemination, J. Agr. Res., 10, 639-648, 1917.

Felsenstein, J.: PHYLIP (phylogeny inference package) version 3.6, 2004, distributed by the author, 2005.

Fierer, N., Liu, Z., Rodríguez-Hernández, M., Knight, R., Henn, M., and Hernandez, M. T.: Short-term temporal variability in airborne bacterial and fungal populations, Appl. Environ. Microbiol., 74, 200-207, 2008.

Fitt, B. D. L., McCartney, H. A., and Walklate, P. J.: The Role of Rain in Dispersal of Pathogen Inoculum, Annu. Rev. Phytopathol., 27, 241-270, 1989.

Foot, V. E., Kaye, P. H., Stanley, W. R., Barrington, S. J., Gallagher, M. and Gabey, A.: Low-cost real-time multi-parameter bio-aerosol sensors, Proceedings of the SPIE - The International Society for Optical Engineering, 711601 (711612 pp.), doi:10.1117/12.800226, 2008.

Fröhlich-Nowoisky, J., Pickersgill, D. A., Després, V. R., and Pöschl, U.: High diversity of fungi in air particulate matter, P. Natl. Acad. Sci., 106, 12814-12819, doi:10.1073/pnas.0811003106, 2009.

Fröhlich-Nowoisky, J., Burrows, S. M., Xie, Z., Engling, G., Solomon, P. A., Fraser, M. P., Mayol-Bracero, O. L., Artaxo, P., Begerow, D., Conrad, R., Andreae, M. O., Després, V. R., and Pöschl, U.: Biogeography in the air: fungal diversity over land and oceans, Biogeosciences, 9, 1125-1136, doi:10.5194/bg9-1125-2012, 2012.

Gabey, A. M., Gallagher, M. W., Whitehead, J., Dorsey, J. R., Kaye, P. H., and Stanley, W. R.: Measurements and comparison of primary biological aerosol above and below a tropical forest canopy 
using a dual channel fluorescence spectrometer, Atmos. Chem. Phys., 10, 4453-4466, doi:10.5194/acp-10-4453-2010, 2010.

Garcia, E., Hill, T. C. J., Prenni, A. J., DeMott, P. J., Franc, G. D. and Kreidenweis, S. M.: Biogenic ice nuclei in boundary layer air over two U.S. High Plains agricultural regions, J. Geophys. Res.-Atmos., 117, D18209, doi:10.1029/2012JD018343, 2012.

Hallett, J. and Mossop, S. C.: Production of Secondary Ice Particles During Riming Process, Nature, 249, 26-28, doi:10.1038/249026a0, 1974.

Hirst, J. M.: Changes in atmospheric spore content: Diurnal periodicity and the effects of weather, Transactions of the British Mycological Society, 36, 375-393, doi:10.1016/s00071536(53)80034-3, 1953.

Hirst, J. M. and Stedman, O. J.: Dry liberation of fungus spores by raindrops, Journal of General Microbiology, 33, 334-344, 1963.

Hoose, C. and Möhler, O.: Heterogeneous ice nucleation on atmospheric aerosols: a review of results from laboratory experiments, Atmos. Chem. Phys., 12, 9817-9854, doi:10.5194/acp-12-98172012, 2012.

Hoose, C., Kristjansson, J. E., and Burrows, S. M.: How important is biological ice nucleation in clouds on a global scale?, Environ. Res. Lett., 5, 024009, doi:10.1088/1748-9326/5/2/024009, 2010.

Huber, L., Madden, L. V., and Fitt, B. D. L.: Rain-splash and spore dispersal: a physical perspective, in: The Epidemiology of Plant Diseases, edited by: Jones, D. G., Springer Netherlands, 348370, 1998

Huber, T., Faulkner, G., and Hugenholtz, P.: Bellerophon: a program to detect chimeric sequences in multiple sequence alignments, Bioinformatics, 20, 2317-2319, doi:10.1093/bioinformatics/bth226, 2004.

Huffman, J. A., Treutlein, B., and Pöschl, U.: Fluorescent biological aerosol particle concentrations and size distributions measured with an Ultraviolet Aerodynamic Particle Sizer (UVAPS) in Central Europe, Atmos. Chem. Phys., 10, 3215-3233, doi:10.5194/acp-10-3215-2010, 2010.

Huffman, J. A., Sinha, B., Garland, R. M., Snee-Pollmann, A., Gunthe, S. S., Artaxo, P., Martin, S. T., Andreae, M. O., and Pöschl, U.: Size distributions and temporal variations of biological aerosol particles in the Amazon rainforest characterized by microscopy and real-time UV-APS fluorescence techniques during AMAZE-08, Atmos. Chem. Phys., 12, 11997-12019, doi:10.5194/acp-12-11997-2012, 2012.

Iannone, R., Chernoff, D. I., Pringle, A., Martin, S. T., and Bertram, A. K.: The ice nucleation ability of one of the most abundant types of fungal spores found in the atmosphere, Atmos. Chem. Phys., 11, 1191-1201, doi:10.5194/acp-11-1191-2011, 2011.

Kaye, P. H., Stanley, W. R., Hirst, E., Foot, E. V., Baxter, K. L., and Barrington, S. J.: Single particle multichannel bio-aerosol fluorescence sensor, Optics Express, 13, 3583-3593, 2005.

Korolev, A.: Limitations of the wegener-bergeron-findeisen mechanism in the evolution of mixed-phase clouds, J. Atmos. Sci., 64, 3372-3375, doi:10.1175/jas4035.1, 2007.

Leach, C. M.: An Electrostatic Theory to Explain Violent Spore Liberation by Drechslera turcica and Other Fungi, Mycologia, 68, 63-86, doi:10.2307/3758898, 1976

Levin, E. J. T., Prenni, A. J., Petters, M. D., Kreidenweis, S. M., Sullivan, R. C., Atwood, S. A., Ortega, J., DeMott, P. J., and Smith, J. N.: An annual cycle of size-resolved aerosol hygroscopicity at a forested site in Colorado, J. Geophys. Res., 117, D06201, doi:10.1029/2011jd016854, 2012.

Lighthart, B.: Mini-review of the concentration variations found in the alfresco atmospheric bacterial populations, Aerobiologia, 16, 7-16, 2000.

Lighthart, B. and Shaffer, B. T.: Airborne bacteria in the atmosphere surface layer: temporal distribution above a grass seed field, Appl. Environ. Microbiol., 61, 1492-1496, 1995.

Lindemann, J., Constantinidou, H. A., Barchet, W. R., and Upper, C. D.: Plants as sources of airborne bacteria, including ice nucleation-active bacteria, Appl. Environ. Microbiol., 44, 10591063, 1982.

Madden, L.: Effects of rain on splash dispersal of fungal pathogens, Canadian Journal of Plant Pathology, 19, 225-230, 1997.

Madelin, T. M.: Fungal Aerosols - A Review, J. Aerosol Sci., 25, 1405-1412, doi:10.1016/0021-8502(94)90216-x, 1994.

Maenhaut, W., Ducastel, G., Hillamo, R. E., and Pakkanen, T. A.: Evaluation of the applicability of the MOUDI impactor for aerosol collections with subsequent multielement analysis by PIXE, Nuclear Instruments and Methods in Physics Research Section B: Beam Interactions with Materials and Atoms, 75, 249-256, doi:10.1016/0168-583X(93)95653-M, 1993

Maki, L. R., Glyan, E. L., Chang-Chien, M. M., and Caldwell, D. R.: Ice nucleation induced by Pseudomonas syringae, Appl. Environ. Microbiol., 28, 456-459, 1974.

Marple, V. A., Rubow, K. L., and Behm, S. M.: A microorifice uniform deposit impactor (MOUDI) - description, calibration, and use, Aerosol Sci. Technol., 14, 434-446, doi:10.1080/02786829108959504, 1991.

Miguel, A. G., Taylor, P. E., House, J., Glovsky, M. M., and Flagan, R. C.: Meteorological influences on respirable fragment release from Chinese elm pollen, Aerosol Sci. Technol., 40, 690-696, doi:10.1080/02786820600798869, 2006.

Möhler, O., Field, P. R., Connolly, P., Benz, S., Saathoff, H., Schnaiter, M., Wagner, R., Cotton, R., Krämer, M., Mangold, A., and Heymsfield, A. J.: Efficiency of the deposition mode ice nucleation on mineral dust particles, Atmos. Chem. Phys., 6, 30073021, doi:10.5194/acp-6-3007-2006, 2006.

Möhler, O., DeMott, P. J., Vali, G., and Levin, Z.: Microbiology and atmospheric processes: the role of biological particles in cloud physics, Biogeosciences, 4, 1059-1071, doi:10.5194/bg-4-10592007, 2007.

Morris, C. E., Georgakopoulos, D. G., and Sands, D. C.: Ice nucleation active bacteria and their potential role in precipitation, Journal de Physique IV, 121, 87-103, doi:10.1051/jp4:2004121004, 2004.

Morris, C. E., Sands, D. C., Vinatzer, B. A., Glaux, C., Guilbaud, C., Buffiere, A., Yan, S., Dominguez, H., and Thompson, B. M.: The life history of the plant pathogen Pseudomonas syringae is linked to the water cycle, ISME J., 2, 321-334, 2008.

Morris, C. E., Sands, D. C., Glaux, C., Samsatly, J., Asaad, S., Moukahel, A. R., Gonçalves, F. L. T., and Bigg, E. K.: Urediospores of rust fungi are ice nucleation active at $>-10^{\circ} \mathrm{C}$ and harbor ice nucleation active bacteria, Atmos. Chem. Phys., 13, 4223-4233, doi:10.5194/acp-13-4223-2013, 2013.

Nikolcheva, L. G. and Bärlocher, F.: Taxon-specific fungal primers reveal unexpectedly high diversity during leaf decomposition in a stream, Mycological Progress, 3, 41-49, 2004.

Packe, G. E. and Ayres, J.: Asthma outbreak during a thunderstorm, The Lancet, 326, 199-204, doi:10.1016/S0140-6736(85)91510- 
7, 1985.

Paul, P. A., El-Allaf, S. M., Lipps, P. E., and Madden, L. V.: Rain Splash Dispersal of Gibberella zeae Within Wheat Canopies in Ohio, Phytopathology, 94, 1342-1349, doi:10.1094/phyto.2004.94.12.1342, 2004.

Pöhlker, C., Huffman, J. A., and Pöschl, U.: Autofluorescence of atmospheric bioaerosols - fluorescent biomolecules and potential interferences, Atmos. Meas. Tech., 5, 37-71, doi:10.5194/amt-537-2012, 2012a.

Pöhlker, C., Wiedemann, K. T., Sinha, B., Shiraiwa, M., Gunthe, S. S., Smith, M., Su, H., Artaxo, P., Chen, Q., Cheng, Y., Elbert, W., Gillles, M. K., Kilcoyne, A. L. D., Moffet, R. C., Weigand, M., Martin, S. T., Pöschl, U., and Andreae, M. O.: Biogenic potassium salt particles as seeds for secondary organic aerosol in the Amazon, Science, 337, 1075-1078, 2012b.

Pöhlker, C., Huffman, J. A., Förster, J.-D., and Pöschl, U.: Autofluorescence of atmospheric bioaerosols - spectral fingerprints and taxonomic trends of native pollen, Atmos. Meas. Tech. Discuss., 6, 5693-5749, doi:10.5194/amtd-6-5693-2013, 2013.

Pöschl, U.: Atmospheric aerosols: Composition, transformation, climate and health effects, Angewandte Chemie-International Edition, 44, 7520-7540, doi:10.1002/anie.200501122, 2005.

Pöschl, U., Martin, S. T., Sinha, B., Chen, Q., Gunthe, S. S., Huffman, J. A., Borrmann, S., Farmer, D. K., Garland, R. M., Helas, G., Jimenez, J. L., King, S. M., Manzi, A., Mikhailov, E., Pauliquevis, T., Petters, M. D., Prenni, A. J., Roldin, P., Rose, D., Schneider, J., Su, H., Zorn, S. R., Artaxo, P., and Andreae, M. O.: Rainforest Aerosols as Biogenic Nuclei of Clouds and Precipitation in the Amazon, Science, 329, 15131516, doi:10.1126/science.1191056, 2010.

Pratt, K. A., DeMott, P. J., French, J. R., Wang, Z., Westphal, D. L., Heymsfield, A. J., Twohy, C. H., Prenni, A. J., and Prather, K. A.: In situ detection of biological particles in cloud ice-crystals, Nature Geosci., 2, 397-400, doi:10.1038/ngeo521, 2009.

Prenni, A. J., Petters, M. D., Kreidenweis, S. M., Heald, C. L., Martin, S. T., Artaxo, P., Garland, R. M., Wollny, A. G., and Pöschl, U.: Relative roles of biogenic emissions and Saharan dust as ice nuclei in the Amazon basin, Nature Geosci., 2, 402-405, doi:10.1038/ngeo517, 2009.

Prenni, A. J., Tobo, Y., Garcia, E., DeMott, P. J., Huffman, J. A., McCluskey, C. S., Kreidenweis, S. M., Prenni, J. E., Pöhlker, C., and Pöschl, U.: The impact of rain on ice nuclei populations at a forested site in Colorado, Geophys. Res. Lett., 40, 227-231, doi:10.1029/2012g1053953, 2013.

Pummer, B. G., Bauer, H., Bernardi, J., Bleicher, S., and Grothe, H.: Suspendable macromolecules are responsible for ice nucleation activity of birch and conifer pollen, Atmos. Chem. Phys., 12, 2541-2550, doi:10.5194/acp-12-2541-2012, 2012.

Richard, C., Martin, J.-G., and Pouler, S.: Ice nucleation activity identified in some phytopathogenic Fusarium species, Phytoprotection, 77, 83-92, 1996.

Robinson, N. H., Allan, J. D., Huffman, J. A., Kaye, P. H., Foot, V. E., and Gallagher, M.: Cluster analysis of WIBS single-particle bioaerosol data, Atmos. Meas. Tech., 6, 337-347, doi:10.5194/amt-6-337-2013, 2013.

Rogers, D. C., DeMott, P. J., Kreidenweis, S. M., and Chen, Y.: A continuous-flow diffusion chamber for airborne measurements of ice nuclei, J. Atmos. Ocean. Tech., 18, 725-741, 2001.
Sands, D. C., Langhans, V. E., Scharen, A. L., and de Smet, G.: The association between bacteria and rain and possible resultant meteorological implications, Journal of the Hungarian Meteorological Service, 86, 148-152, 1982.

Schloss, P. D., Westcott, S. L., Ryabin, T., Hall, J. R., Hartmann, M., Hollister, E. B., Lesniewski, R. A., Oakley, B. B., Parks, D. H., Robinson, C. J., Sahl, J. W., Stres, B., Thallinger, G. G., Van Horn, D. J., and Weber, C. F.: Introducing mothur: Open-Source, Platform-Independent, Community-Supported Software for Describing and Comparing Microbial Communities, Appl. Environ. Microbiol., 75, 7537-7541, doi:10.1128/aem.01541-09, 2009.

Schumacher, C. J., Pöhlker, C., Aalto, P., Hiltunen, V., Petäjä, T., Kulmala, M., Pöschl, U., and Huffman, J. A.: Seasonal cycles of fluorescent biological aerosol particles in boreal and semi-arid forests of Finland and Colorado, Atmos. Chem. Phys. Discuss., 13, 17123-17158, doi:10.5194/acpd-13-17123-2013, 2013.

Sesartic, A., Lohmann, U., and Storelvmo, T.: Modelling the impact of fungal spore ice nuclei on clouds and precipitation, Environ. Res. Lett., 8, 014029, doi:10.1088/1748-9326/8/1/014029, 2013.

Sinha, B. W., Hoppe, P., Huth, J., Foley, S., and Andreae, M. O.: Sulfur isotope analyses of individual aerosol particles in the urban aerosol at a central European site (Mainz, Germany), Atmos. Chem. Phys., 8, 7217-7238, doi:10.5194/acp-8-7217-2008, 2008.

Staley, J. T. and Konopka, A.: Measurement of in situ activities of nonphotosynthetic microorganisms in aquatic and terrestrial habitats, Annu. Rev. Microbiol., 39, 321-346, 1985.

Sullivan, R. C., Petters, M. D., DeMott, P. J., Kreidenweis, S. M., Wex, H., Niedermeier, D., Hartmann, S., Clauss, T., Stratmann, F., Reitz, P., Schneider, J., and Sierau, B.: Irreversible loss of ice nucleation active sites in mineral dust particles caused by sulphuric acid condensation, Atmos. Chem. Phys., 10, 1147111487, doi:10.5194/acp-10-11471-2010, 2010.

Taylor, P. and Jonsson, H.: Thunderstorm asthma, Current Allergy and Asthma Reports, 4, 409-413, doi:10.1007/s11882-0040092-3, 2004.

Taylor, P. E., Flagan, R. C., Miguel, A. G., Valenta, R., and Glovsky, M. M.: Birch pollen rupture and the release of aerosols of respirable allergens, Clin. Exp. Allergy, 34, 1591-1596, doi:10.1111/j.1365-2222.2004.02078.x, 2004.

Tobo, Y., Prenni, A. J., DeMott, P. J., Huffman, J. A., McCluskey, C. S., Tian, G., Pöhlker, C., Pöschl, U., and Kreidenweis, S. M.: Biological aerosol particles as a key determinant of ice nuclei populations in a forest ecosystem, J. Geophys. Res., in review, 2013.

Vali, G.: Quantitative evaluation of experimental results on heterogeneous freezing of supercooled liquids, J. Atmos. Sci., 28, 402-409, http://dx.doi.org/doi:10.1175/15200469(1971)028<0402:qeoera > 2.0.co;2, 1971.

Weisburg, W. G., Barns, S. M., Pelletier, D. A., and Lane, D. J.: 16S ribosomal DNA amplification for phylogenetic study, J. Bacteriol., 173, 697-703, 1991.

White, T. J., Bruns, T., Lee, S., and Taylor, J.: Amplification and Direct Sequencing of Fungal Ribosomal RNA genes for Phylogenetics, in: PCR Protocols: a Guide to Methods and Applications, edited by: Innis, M. A., Gelfand, D. H., Sninsky, J. J., and White, T. J., Academic Press, Inc., New York, 315-322, 1990. 